\title{
Między wolnością krytycznej lektury a obroną kanonu. O szkole, nauczycielach i szkolnej polonistyce rozmawiają: prof. dr hab. Inga Iwasiów, prof. dr hab. Anna Janus-Sitarz, prof. dr hab. Piotr Śliwiński, dr hab. Krzysztof Biedrzycki, prof. UJ
}

\author{
Between Freedom of Critical Reading and Safeguarding the Canon. \\ Prof. Inga Iwasiów, Prof. Anna Janus-Sitarz, Prof. Piotr Śliwiński, \\ and Prof. Krzysztof Biedrzycki in Conversation on the School System, Teachers, \\ and Teaching Polish in School
}

Krzysztof Biedrzycki (K.B.): W jakiej sytuacji znalazła się szkoła w naszej epoce? Przystaje do niej, odpowiada na jej wyzwania czy pozostaje anachronicznym reliktem czasów minionych i ich mentalności? Właściwie szkoła z natury rzeczy jest konserwatywna, to znaczy jej pochodzenie jest takie, że ci, którzy są starsi, przekazują wiedzę i umiejętności młodszym. Siłą rzeczy przekazują to, co oni już znają, więc z przeszłości przenoszą w teraźniejszość, ale z drugiej strony obecne jest też oczywiste wychylenie w przyszłość, bo młodzi ludzie uczą się z perspektywą całego życia, które na nich czeka. W naszych czasach chyba jednak ten prosty przekaz, jeśli nie skończył się, to przynajmniej jest utrudniony, dlatego że to, co jest zapowiedzią przyszłości, tak szybko się zmienia, iż właściwie młodzi ludzie są szybciej w tej przyszłości, z jej wymaganiami, niż ci, którzy im swoją wiedzę mają przekazywać i nie tylko za młodymi, ale i za wymaganiami świata nie nadążają. Nasuwają się zatem pytania o sytuację cywilizacyjną: jak się odnajduje czy też nie odnajduje szkoła w tym wszystkim? jak to wyzwanie cywilizacyjne wpływa na szkołę z państwa perspektywy?

Anna Janus-Sitarz (A.J.S.): Już od kilku lat odbywają się debaty na temat wpływu wyzwań cywilizacyjnych na szkołę i zmieniających się oczekiwań wobec jej przyszłych absolwentów. Na pierwszym Kongresie Dydaktyki Polonistycznej w 2013 roku relacjonowałam wyniki badań zespołów amerykańskich, których reprezentanci, z uniwersytetów, stowarzyszeń, a także pracodawcy, mówili o tym, jakie kompetencje będą potrzebne w 2020 roku. Te kompetencje zawsze są ważne: krytyczne myślenie, rozwiązywanie problemów, komunikowanie, 
inteligencja emocjonalna, współpraca, inicjatywa i samodecydowanie o własnym życiu, umiejętność funkcjonowania w wielokulturowym środowisku itd. Te same umiejętności, które są niezbędne do życia teraz i w przyszłości, zostały wskazane w badaniach, których wyniki nasi socjologowie, pod kierunkiem Jarosława Górniaka, przedstawiali na kongresie Instytutu Badań Edukacyjnych i opublikowali w tomie Kapitat ludzki. Przeprowadzono te badania wśród polskich pracodawców pod kątem tego, czego oczekują oni od ludzi, którzy wkrótce wejdą na rynek pracy, jakie będą szczególnie oczekiwania przyszłości. I powiedzmy tu wyraźnie: właściwie rozwój tych wszystkich kompetencji, o których była mowa, zapewnia kontakt $\mathrm{z}$ literaturą. Nawet obecni na kongresie pracodawcy potwierdzali, że to właśnie na lekcjach języka polskiego pojawiają się szczególne możliwości rozwijania sprawności komunikowania się, umiejętności wczuwania się w drugiego człowieka, gotowości do funkcjonowania w wielokulturowym środowisku, zetknięcia z innymi opcjami, odmiennymi poglądami, umiejętności negocjowania, rozwiązywania problemów. Nauczyciele mają coraz większą świadomość, że te wszystkie kompetencje są ważne i powinni je rozwijać u swoich uczniów. Organizują więc na przykład różne projekty i udział w tych projektach w pewien sposób kształtuje te niezbędne umiejętności.

Natomiast, prawdę powiedziawszy, dla mnie najważniejszą kwestią i czymś, co wydaje mi się słabo obecne w polskim dyskursie o szkole, jest podejście do takiego pojęcia jak trudność. Młodzi ludzie często zbyt szybko zrażają się przeszkodami: ta książka jest trudna, zaczynam tę książkę i po trzech stronach rzucam, bo ona jest niezrozumiała. Umiejętność pokonywania trudności w różnych dziedzinach - jest niedoceniana, a przecież ważna. Na przykład w szkołach angielskich niesamowicie ceni się trudność jako wartość, jako taki walor dodatkowy. Jeżeli jest trudność, to znaczy, że pojawia się jakieś wyzwanie, jakaś szansa, która otwiera nowe możliwości. Jeżeli napotykasz trudności, to nie jest żadna porażka, wprost przeciwnie: to znaczy, że możesz coś przekroczyć, coś odkryć. Natomiast u nas funkcjonuje taki schemat: kiedy nauczyciel pyta, czy ktoś czegoś nie rozumie, wszyscy wszystko rozumieją. Wstydzą się przyznać, że nie rozumieją.

K.B.: Często w szkole młodzi ludzie są wręcz karani za to, że nie rozumieją.

A.J.S.: Sama organizacja tekstu poetyckiego dowartościowuje trudność: jeżeli jest metafora, to ona po to jest, żeby wyhamować, żeby to było niejasne, trudne, bo to wtedy jest ważne, bo nas zatrzymuje. Jeśli widzimy gładkie zdania, to lecimy dalej, często bezrefleksyjnie.

K.B.: Nawet studenci boją się trudności...

A.J.S.: Dlatego dobrze dowartościować Derridę, dekonstrukcjonizm i poszukiwanie niejasnych miejsc... 
Inga Iwasiów (I.I.): To jest bardzo ciekawe i chętnie do tego nawiążę, bo myślę, że w całej filozofii, w której tkwimy, w filozofii szkoły, ale też w filozofii społecznej, w przekazie kultury kwestia rozwiązywania trudności jest nastawiona na odniesienie sukcesu, to znaczy właśnie na przezwyciężanie, i myślę także, że szkoła - tak jak wiele sfer życia społecznego - jest zarażona fetyszem nowoczesności, postępu, wydolności, produktywności, a więc wobec tego również zażegnywania tych ewentualnych trudności i kamuflowania ich. Nawet jeśli mówimy o komunikowaniu się, to nie mówimy o komunikowaniu jako takim, tylko mówimy o skomunikowaniu, o efektywnym i modelowym porozumieniu, nasuwającym skojarzenie z korporacją, w której rozwiązuje się problemy metodami coachingu. I w zasadzie może nawet tak bym to sformułowała, że mamy taki coachingowy model myślenia - on nie jest wprost stosowany w szkole, ale szkoła jednak jest przesiąknięta tym trybem myślenia. Nawet jeśli szkoła nie jest zorganizowana korporacyjnie, a metody nauczania nie korzystają ze schematu treningu, to funkcjonuje w warunkach, w których postawa proproduktywna i samonaprawcza jest pożądana. Widzę tu konflikt pomiędzy przeciwstawnymi wartościami. Wektorowe odsunięcie, dlatego że jeśli nastawimy się na sukces, postęp, osiąganie celu, to jednocześnie zostawimy za burtą wszystko, co jest chaosem, co jest linią poszukującego rozwoju, niepowodzenia, strefy ciemne, a więc właściwie wszystko to, co jest związane także z cyklem rozwojowym młodego człowieka. Budujemy drabinę, po której młody człowiek ma iść w górę, żeby stać się tym idealnym pracownikiem, korpoludkiem, częścią maszynki, w której będzie sprawnie działał. Dlatego bardzo mi się podoba, kiedy Pani Profesor mówi o wadze i roli trudności, ale jednocześnie widzę tę podwójność: czy to ma być trudność do przezwyciężenia, czy to ma być trudność, na którą się po prostu czasem zgodzimy. Wydaje mi się, że dlatego interpretacja jest tak ważna, czy raczej czytanie, bo interpretacja również mogłaby nas wieść do jakiegoś rozwiązania, a czytanie może nas zwodzić, może nas wieść na manowce, może być niekonkluzywne i w tym sensie lepiej chyba oddaje taki stan, w którym nie jesteśmy tylko produktywni, ale jesteśmy po prostu w drodze. I teraz pojawia się pytanie: czy możemy być w szkole w drodze, skoro szkoła jest zarażona fetyszem nadążania? Samo zadanie pytań, jaki pracownik będzie potrzebny, jaki człowiek będzie potrzebny, jakie kompetencje będą niezbędne, oznacza, że my chcemy wyprodukować tego idealnego absolwenta. To samo robimy zresztą na studiach, więc nie zostawiamy w zasadzie żadnego marginesu na błądzenie i poszukiwanie, opracowujemy teleologiczny model, chcemy sprostać fetyszowi nowoczesności i mamy jeszcze coś, o czym chciałabym powiedzieć i co wydaje mi się wszystko komplikować. Otóż mamy kontrolę. Wydaje mi się, że współczesna szkoła jest na każdym poziomie zarażona kontrolą, ideałem skontrolowania, ideałem transparentności swoich działań. Kontrolują szkołę państwo, kuratorium, rodzice, a także uczniowie kontrolują nauczycieli i nauczyciele uczniów. Nie wiem, czy w takim modelu kontroli możliwe jest przyjazne egzystowanie w tym błądzeniu. $Z$ jednej strony celowość 
i fetysz nadążania, bycia wydolnym w społeczeństwie, w którym przyjdzie żyć młodym ludziom, z drugiej kontrolowanie, więc jeśli jestem niewydolny, to zostanę w swojej niewydolności skontrolowany, skatalogowany i skorygowany.

K.B.: To jest rzeczywiście rzecz i ciekawa, i niepokojąca, że w społeczeństwie, które deklaratywnie stawia na demokrację, na współpracę, właściwie zgubiliśmy gdzieś tę współpracę, stawiamy na konkurencję. To jest oczywiście w jakiś sposób przeniesienie wzorców korporacyjnych, gdzie współpraca jest dozwolona w pewnym zakresie wspólnego rozwiązania jakiegoś problemu, ale jako korporacja musimy się podporządkować zasadom. Natomiast jeśli chodzi o kwestie komunikacyjne i o to, że mamy taki fetysz czy potrzebę dopełnienia komunikacji, to podam taki przykład: bardzo chętnie czytam ze studentami przepiękny wiersz Stanisława Barańczaka Ptakata w nocy, ale nie jej ptacz go zbudzit i pierwsza odpowiedź, której udzielają studenci, jest taka, że to utwór o problemach komunikacyjnych, że gdyby bohaterowie potrafili rozmawiać ze sobą, to by całego problemu opisanego w wierszu nie było. I musimy długo się wczytywać, żeby dojść do tego, że problem jest zupełnie inny, że nie chodzi o to, że nie potrafią, ale że się nie da, że są sytuacje, w których musimy się zgodzić na to, że komunikacji nie będzie.

I.I.: To oczywiście bardzo anarchicznie brzmi, co my tu wszyscy teraz powiedzieliśmy, bo w społeczeństwie, które cierpi na brak skomunikowania się, mówimy, że to skomunikowanie nie może być fetyszem, ale ja sądzę, że tak właśnie jest, że nie powinno być fetyszem. Ponieważ wiemy, że idealna komunikacja nie jest możliwa, to być może powinniśmy postawić jako jedną z dróg przed dziećmi, przed młodzieżą taką możliwość, że z szacunkiem, ale pozostawiamy margines, że właśnie nie wszędzie musimy dojść do wspólnych konkluzji i nie nastąpi spisanie postanowień końcowych, że emocje są ważne, bo wydaje mi się, że ten przykład wiersza Barańczaka o tym mówi: wstydzimy się powiedzieć, że może chodzić po prostu o emocje i one nie będą wyrażone w żadnych języku konkluzji.

Piotr Śliwiński (P.Ś.): Mówimy o współpracy i o wspólnocie, bardzo chętnie deklarujemy, że wspólnota jest nam droga, a równocześnie dość trudno nam się przyznać, że nie potrafimy ze sobą współpracować. Nie umiejąc współpracować, ze wspólnoty tworzymy coś w gruncie rzeczy bardzo jałowego, płytkiego, a nawet niebezpiecznego. Mówiąc o współpracy, mam na myśli umiejętność bycia ze sobą, a nie zdobywania czegoś, czym się później podzielimy. Porzucamy wspólnotę na rzecz populizmu, bardzo uwyraźniających, jednoznacznych i represywnych określeń, czym ona jest, z czego się składa, na czym się opiera. Powiedziawszy to, uświadamiam sobie, że problemy, o których mówimy, nie są problemami tylko szkoły, ale pewnie naszego społeczeństwa. I w jaki sposób szkoła miałaby się uleczyć przeciwko choremu na te wszystkie dolegliwości 
społeczeństwu? Tu jest, z praktycznego punktu widzenia, nierozwiązywalny, aporetyczny problem. Jak by to się właściwie miało zdarzyć? Na dobrą sprawę jedyne takie ustanowienie czegoś, co byłoby zaczynem inaczej wyobrażonej szkoły, bo to jest do wykonania, choć nikt się do tego nie kwapi, to jest jednak przywrócenie prestiżu, autorytetu i osobowości nauczycielowi - od materialnej strony poczynając, ponieważ nie może być nauczyciel pariasem tego społeczeństwa, bo to społeczeństwo nie będzie miało nauczycieli, tylko pariasów, a to jest jednak bardzo niekorzystna sytuacja. Następnie, dopowiadając do tego, co powiedzieliście wcześniej: kiedy mówimy o kształtowaniu takiej wspólnoty przez teksty, wówczas, mając literaturę w środku, sercu, wyobraźni, w centrum każdego obrazu kultury, nie możemy na niej poprzestać, bo rzeczywistość młodego człowieka dzisiaj jest rzeczywistością gry komputerowej, serialu telewizyjnego. W pewnym momencie na zajęciach pomyślałem, że gdyby każdy ze studentów, który opowiadał mi o różnych serialach - w większości czy prawie wszystkie były mi nieznane - przeczytał jedną współczesną powieść, to byłby człowiekiem dość dobrze oczytanym we współczesnej literaturze. Literatura jako źródło przyjemności została zastąpiona pod tym względem przez serial, bo on zaspokaja potrzebę opowieści, jest właściwie taką powieścią współczesną, w innej postaci funkcjonującą i dostarczającą tych przyjemności, które są bardziej zrozumiałe czy dostępne. Trzeba by wziąć pod uwagę całą sieć i te wszystkie internetowe związki, a czasami związki, które tam się dokonują... Jesteśmy przywiązani do myślenia za pomocą symboli, kapitału symbolicznego, tradycji, która jest rodzajem kumulacji wartości, a zdaje mi się, że dla młodych ludzi, jeśli nie uwzględnić sposobu, w jaki oni rozgrywają relacje ze sobą na co dzień, tradycja i zasoby kulturowe w gruncie rzeczy przestają wiele znaczyć. Jeśli się do nich odnosza, to w sposób upraszczający, etykietujący i represywny: żyję w sieci, ale kiedy mnie spytają, kim jestem, to odpowiem, że jestem Polakiem, mam koszulkę z żołnierzami wyklętymi itd. i nie cierpię tych, którzy myślą o Polsce inaczej, niż myśleć się powinno. Dlaczego tak się dzieje? Dlaczego ta sieć, życie bardzo różnorodne, tymczasowe, chwilowe, rozmnożone przez wszystkie kontakty i interakcje, z którymi mają na co dzień do czynienia, nie nauczyło ich życia nieco bardziej złożonego, nieco mniej dogmatycznego, ortodoksyjnego w innej dziedzinie? Dlaczego internet nie uodparnia na pewnego rodzaju ortodoksję, dogmatyzm, resentyment i odrzucenie? Dlatego że być może o tych doświadczeniach w sieci, w życiu wirtualnym się po prostu nie mówi. Szkoła uważa to za pewną ciekawostkę, na przykład nowe media, ale nie traktuje tego do końca jako swojej dziedziny.

A.J.S.: Jeśli można tak ad vocem, jednym z najważniejszych problemów jest to, że my często jako nauczyciele akademiccy czy szkolni nie zauważamy, że mamy do czynienia z zupełnie innym partnerem tych naszych edukacyjnych działań: on się zmienia i my musimy brać pod uwagę te uwarunkowania, zmiany. Robię wiele badań na temat przyjemności czytania i ci młodzi ludzie, którzy bardzo 
często są inteligentni, mówią na przykład: „ja właściwie to chętnie bym czytał, gdyby było po co lub gdyby to miało jakikolwiek sens", i podają takie argumenty, których nie możemy lekceważyć. Mianowicie na przykład na pytanie, dlaczego wybierają aktywność w internecie, a nie aktywność z książką, nastoletni chłopcy odpowiadają, że grając w grę komputerową, mają wpływ na wirtualną rzeczywistość, bo tam mogą zmieniać narrację, mogą wchodzić w wykreowany świat, mogą go przestawiać, mogą stać się jego bohaterem. Nie widzą takiej możliwości w literaturze. Nie oznacza to, że jej nie ma, tylko że oni jej nie widzą, ich tego nie nauczono, nie pokazano im, że czytając, stają się współtwórcami tej literatury, bo przecież tyle książek, ilu czytelników, za każdym czytaniem to jest inna książka, bo wnosi się swoje doświadczenie.

Mowa była tutaj o narracji. Człowiekowi narracja jest potrzebna do samookreślenia się i literatura w jakiejś mierze pokazuje, jak tworzyć te narracje, tym bardziej warto tym uczniom dać szansę tworzenia tej narracji o samym sobie. Mnie niegdyś referat profesor Barbary Myrdzik o potrzebie tworzenia opowieści zainspirował do prowadzenia takich zajęć ze studentami, na których proszę ich o wyciągnięcie kalendarzyków albo list adresowych w telefonach, a następnie o przeczytanie sobie tego spisu, gdzie są nazwiska, które czasem nic im już nie mówią, albo imiona ludzi, z którymi się już nie spotykają, czy też wprost przeciwnie, które znaczą dla nich wiele, albo żeby zwrócili uwagę na to, jak je zapisują: Basieńka, Misiu, Ojciec itd. Zachęcam ich, by zastanowili się, co ten spis mówi o nich samych, i by na tej podstawie napisali opowieść o sobie samych. Mówię to wszystko, ponieważ najciekawsze są potem dyskusje na temat tego, po co nam to jest, po co nam są potrzebne narracje o nas samych. Może to być też klucz, którym trafimy do uczniów, do młodych ludzi, którzy nazwani są pokoleniem selfie, bo jeżeli robią fotografie, to jednak najczęściej sobie. Dlatego też tworzenie narracji o sobie samych i uczenie się z książek tworzenia tych opowieści może być dla nich jakąś odpowiedzią na pytanie: „po co mi to?" i sposobem otwarcia ich na literaturę.

P.Ś.: To prof. Iwasiów wie, jak z czegoś, co istniało w internecie, może powstać książka, chociaż to, co powstało w internecie, też było literaturą. Takich przykładów rzeczy, które z Facebooka stają się książką poetycką, jest kilka, może znacznie więcej. W ten sposób ceniona i mająca już niemały dorobek Julia Szychowiak tworzy swoje książki. Pokazanie tego uczniom, jak myślę, byłoby dla nich instruktywne, mogłoby być jakiegoś rodzaju impulsem. Chodzi mi jednak jeszcze o coś innego. Otóż zastanawiam się, czy dałoby się wyperswadować szkole strzelanie focha? Bo szkoła naprawdę strzela focha i to jest jej słabość. Podczas kongresu dwa lata temu w Lublinie pani profesor Halina Zgółkowa mówiła o tym, że należałoby z uczniami omawiać kwestie języka zarzuconego wulgaryzmami. Czy szkoła o wulgaryzmach mówi? Bardzo wątpię, choć może ktoś mówi, może ktoś jest tak ekscentryczny. Wulgaryzmy - a jeżdżę podmiejskim autobusem, więc wiem i naprawdę się nie zgrywam - są w języku studentów 
i uczniów, bez względu na wiek, bez względu na płeć, bez względu na charakter szkoły, wszechobecne.

K.B.: Są nawet w parlamencie...

P.Ś.: Oczywiście, że są, także na uniwersytecie, w gabinetach profesorskich i gdzie chcemy, ale w szkole na lekcji ich nie ma.

I.I.: Na zajęciach ze studentami już bywają...

P.Ś.: Tak, ale mam na myśli jako problem do dyskusji i uświadomienia...

I.I.: Czy jako problem? Bo mówisz, żeby nie strzelać focha... To oznaczałoby nie normalizować...

P.Ś.: Nie normalizować, nie przedstawiać jako rzeczy naturalnej, uznać za dopuszczalny zwyczaj, ale uczynić tematem rozmowy, sproblematyzować, pokazać życiowe koszty takiego języka. A nauczyciele zachowują się tak, jakby nie jeździli komunikacją miejską, nie stali na przystanku, w kolejce do kina - jakby żyli w jakiejś bańce, co przecież jest oczywistą nieprawdą. Krótko mówiąc, tu nie chodzi o to, żeby się podlizywać uczniom, rozgrzeszać ich z wulgarnego, ubogiego języka, z języka nienawiści, ale o pewną pracę. Tymczasem szkoła nie chce zajmować się tym, jak uczeń mówi i co czyta. Ileż czasu minęło, zanim pojawiło się fantasy w horyzoncie zainteresowań szkoły.

I.I.: Andrzej Sapkowski się pojawia, kiedy młodzież go już nie czyta (korekta: znów czyta, za sprawą serialu).

P.Ś.: Zabawna niepunktualność.

A.J.S.: Niektórzy nauczyciele podejmują jednak takie tematy jako przedmiot rozważań, na przykład: miejsce i sens funkcjonowania wulgaryzmów, gdzie i kiedy są one uzasadnione. Profesor Danuta Wesołowska mówiła niegdyś na naszych zajęciach: „no, a co taki góral ma zrobić, jak mu siekiera na nogę spadnie? Przecież nie powie: o jejku”. Powtarzam jej słowa swoim studentom, bo pojawia się tu kwestia tego, kiedy użycie jest uzasadnione, kiedy wzmocnione, kiedy agresywne, a kiedy może kogoś obrażać i w jakich kręgach. Przecież wiadomo, że teraz funkcjonują słowa, które mnie ciągle jeszcze nie przejdą przez usta, natomiast wcale nie są słowami wulgarnymi z punktu widzenia młodzieży. Wiem, że temat jest podejmowany przez niektórych, choć zapewne nielicznych nauczycieli, choć nie ma go już w podstawie programowej. 
K.B.: W tej odchodzącej podstawie zwracano uwagę na to, by mówić o konsekwencjach używania wulgaryzmów, ale ilu nauczycieli to realizowało, tego też nie wiadomo.

I.I.: Z tego, o czym mówimy, wynikałaby jeszcze jedna sprzeczność. Z jednej strony mamy fetysz nowoczesności, a z drugiej strony to coś, co Piotr nazywa strzelaniem focha, bo faktycznie tak jest. Podczas gdy nasi uczniowie żyją w świecie, nazwę go „aktualnym”, my teoretyzujemy na temat nowoczesności i ponowoczesności. Aspirujemy razem z uczniami do świata wyimaginowanego, który miałby ich przygotowywać do jakiejś idealnej lub korporacyjnej rzeczywistości, natomiast nie uwzględniamy tych światów, w których oni żyją, czyli tych narracji, w których oni funkcjonują, bo funkcjonują też w narracjach i my to z teoretycznego punktu widzenia obrabiamy bezustannie, pokazujemy równoważność tych narracji, ale jednocześnie oczywiście mamy hierarchię, w której chcielibyśmy sprowadzić do klasycznego czytania także tych uczniów, którzy opowiadają już sobie na inne sposoby. Drugi wątek to ten, w którym, Piotrze, mówisz o autorytecie nauczyciela. Uważam, że to jest kluczowe: żyjemy w rzeczywistości, w której nie zostały w żaden sposób rozwiązane problemy nas wszystkich, nie środowiska nauczycielskiego, tylko właśnie nas wszystkich poprzez zlekceważenie protestów nauczycieli i postulatów nauczycieli. Ponieważ mówimy o tych postulatach jako o postulatach grupy zawodowej, zapominając o tym, że oni mówią o nas wszystkich. Każda dyskusja na temat sytuacji w zawodzie nauczycielskim powinna być rozszerzona na kontekst. To nie jest sytuacja w zawodzie - to jest sytuacja każdego z nas, kto był uczniem, ma dzieci w szkole lub będzie komunikował się z absolwentami szkół pracującymi w różnych zawodach. Zdefiniowanie, zredefiniowanie pozycji nauczycieli, wymaga uświadamiania, że nauczyciel ma zbyt mało instrumentów działania, że jest ekonomicznie źle traktowany, ustawiony w sytuacji bezustannej kontroli i interwencji ze strony nie tylko aparatu państwa i swoich przełożonych, ale także nas jako rodziców. To jest coś, co obserwuję i co mnie zastanawia, i być może nie mam dostatecznej wiedzy na ten temat, ale wydaje mi się, że mamy do czynienia z zarzuceniem pewnego modelu, który sama znam ze swojej praktyki szkolnej czy jeszcze z praktyki życia szkolnego moich dzieci, modelu, w którym relacja uczeń-nauczyciel była relacją, która nie rozgrywała się w takiej bezustannej kontrolującej perspektywie - także rodzicielskiej. Miała ona swoją dynamikę, która oczywiście nie była idealna, ale jednak zakładała, że uczeń jest w orbicie oddziaływań innego dorosłego człowieka niż rodzic i że ma to swoje wychowawcze znaczenie. Wydaje mi się, że ta relacja została zrujnowana przez dzisiejszą szkołę pełną kontroli: przez dzienniki elektroniczne, przez to, że uczeń jeszcze nie dostał jedynki, a już rodzic o tym wie i w związku z tym oboje - i uczeń, i nauczyciel - są pod presją rodzica, czyli nic się nie może rozegrać w tym środowisku, które bym widziała jednak jako wartościowe równoległe środowisko wobec środowiska rodzinnego. Właściwie 
wyeliminowaliśmy taką strukturę, w której młody człowiek dojrzewa także w tym środowisku i nie traktuje szkoły jako delegacji z domu. Współczesne dziecko jest bezustannie przez dom obserwowane, kontrolowane i korygowane - dotyczy to i dziecka, i nauczyciela.

P.Ś.: Całkowicie się zgadzam. Miałem okazję obserwować to na swoim synu, który jeszcze nie tak dawno chodził do liceum, i tak nieprawdopodobnej arogancji społecznej wśród rodziców nie widziałem. Dzieje się tak dlatego, że nauczyciel jest w oczach rodziców słaby społecznie, podległy im. W Polsce każdy jest mądrzejszy od nauczyciela, bo jest dziennikarzem i więcej zarabia, bo ma firmę i więcej zarabia, bo jest urzędnikiem, bo udało mu się nie być nauczycielem. Czynnik ekonomiczny jest istotny, ale równie istotne jest to, że nauczyciel jest totalnie umocowany w porządku - bez możliwości awansu, bez możliwości bycia docenionym. Oczywiście ktoś powie, że przecież są doceniani, ale jaki procent pracujących ma na to szansę? Nauczyciel jest uwięziony w bardzo spłaszczonej strukturze, która równocześnie jest strukturą pogardy, zinternalizowanej, przyswojonej. Mnie się wydaje, że teorie lepszego uczenia w tych warunkach są, prawdę mówiąc, również trochę aroganckie w stosunku do ludzi skazanych na to położenie.

K.B.: Przy czym ja bym powiedział, że na to się nakłada jeszcze jeden element, ponieważ z drugiej strony nauczyciel jest postrzegany jako przedstawiciel państwa, ale słaby przedstawiciel państwa, dlatego że nikt nie pójdzie do sędziego, nawet do policjanta i się na nim nie wyżyje, natomiast nauczycielowi, który jest eksponentem władzy w oczach społeczeństwa, można powiedzieć, że źle robi, że jest zły, słaby - trochę taki mechanizm kozła ofiarnego, na którego zrzucimy grzechy społeczeństwa.

P.Ś.: Jesteśmy zobowiązani do respektowania ideologicznej koncepcji współpracy, której nie umiemy wprowadzić w życie. Mówimy o współpracy, ale nie wiemy, jak współpracować. Szkoła i rodzice nie współpracują. Ktoś nałożył komuś uzdę pod szyldem owej kooperacji, wymiany doświadczeń etc. Na przykład postawienie nauczyciela przed komisją dyscyplinarną to bułka z masłem dla rodzica, który ma na to ochotę. Zanim nauczyciel wywikła się z oskarżeń, miną miesiące infamii, nieprzyjemności, czasami jeszcze gorszych doświadczeń. Ta łatwość stygmatyzowania wydaje się uderzająca, nawet jeśli pamiętać, że nauczyciele nie są w ogólności aniołami. Jak my wszyscy.

A.J.S.: Słyszałam opowieści studentów po praktykach, podczas których obserwowali, jak uczeń mówi do nauczycielki: „mój ojciec nie przeczytał ani jednej książki, a zarabia więcej niż pani”. Pouczanie nauczycieli przez rodziców, że za dużo czasu poświęcają na dany temat, że dziecko nie ma tyle czasu na czytanie lektury i nauczyciel powinien pokazać mu jednak adaptację - takie rzeczy się 
zdarzają, a jedynym wyjściem z sytuacji jest rzeczywiście finansowe docenienie tej pozycji, tak jak to się na przykład dzieje w Szwecji, Finlandii, w krajach skandynawskich, gdzie jest dziesięciu kandydatów na jedno miejsce na studiach nauczycielskich, kończą je najlepsi z najlepszych, i ten zawód ma w związku z tym bardzo wysoki prestiż. Tam stopień zaufania społecznego wobec nauczycieli jest po prostu ogromny, więc jeżeli nauczyciel podejmuje decyzję, żeby coś zrobić, to rodzic ufa, że robi to na pewno dla dobra dziecka.

K.B.: Chciałbym jeszcze jeden wątek poruszyć. W uzasadnianiu dokonanej ostatnio reformy wyrażano pewnego rodzaju konserwatywny lęk. To, o czym mówiliśmy, o perspektywie cywilizacyjnej, o zagrożeniach z tym związanych, po stronie konserwatywnej jest postrzegane nie tylko jako skonkretyzowane niebezpieczeństwo, ale także jako generalne, cywilizacyjne niebezpieczeństwo. Zrozumiałem, że dla konserwatystów uśmierzeniem tego lęku będzie odtworzenie tradycyjnego modelu szkoły, między innymi jeśli chodzi o język polski z całym tym bagażem tradycyjnego kanonu, który został właściwie przepisany wprost, z pewnymi korektami, z lat siedemdziesiątych i osiemdziesiątych. I stąd właściwie moje pytanie o ów lęk. Szkoła jest pewnego rodzaju modelem, odbiciem tego, co się dzieje w społeczeństwie, i ta niepewność co do przyszłości, sposób, w jaki traktujemy nauczyciela, problemy programowe - one odzwierciedlają to, co dzieje się wśród nas jako społeczeństwie. Równolegle pojawiają się lęki, że właściwie coś gubimy, że ucząc na przykład skutecznej komunikacji, równocześnie gubimy albo unicestwiamy zmitologizowany czy też realny kod kulturowy, że gdzieś coś nam się gubi i jeśli my pozwolimy, żeby szkoła szła w kierunku takiego rozluźniania, rozmowy między uczniami a nie twardej wiedzy, twardego powtarzania kanonu, to wtedy przestaniemy być Polakami czy też po prostu ludźmi cywilizacji, którą znamy. I teraz moje pytanie dotyczy tego, jak my, którzy tutaj rozmawiamy, potrafilibyśmy odpowiedzieć temu, kto się boi.

I.I.: Dziś lęk podpowiada ucieczkę w jednowymiarowy świat. Bezpiecznika dostarcza pozornie bezpieczna hipokryzja. Lęk i hipokryzja pogłębiają nieadekwatność dyskursu szkolnego, ale też innych odmian dyskursów oficjalnych wobec doświadczenia kulturowego i kodów, którymi się posługują młodzi ludzie. To jest ustawienie szkoły jako pola martwego, pola gestów, które są do wyuczenia i odtwarzania, które można później reprodukować w życiu publicznym. Wracamy tym samym do schematu akademijnego, do powtarzania pewnych rytuałów i sloganów, ale one będą coraz bardziej odbiegały od życia dzieci i młodzieży. W związku z tym kształcenie oparte na lęku, hipokryzji, wykluczeniu jest w zasadzie raczej pracą na bunt. Nie jesteśmy w stanie uwięzić ludzi w tych uproszczonych schematach. Oni do pewnego momentu mogą odrabiać zadanie, powtarzać formułki, ale kiedy sami zauważą, że wyćwiczone w szkole gesty są niewydolne, to znaczy, że są tylko w jakiś sposób operacyjne w mechanizmie 
przystosowywania się, ale zarazem oddzielone choćby od przyjemności obcowania z kulturą, są sprzeczne ze sposobem spędzania wolnego czasu, są też do jakiegoś stopnia martwe i niesprowadzalne do doświadczenia jednostkowego, okaże się, że właściwie uzbrajamy bombę. I to bym powiedziała tym, którzy chcą kanonu jednowartościowego, anachronicznego, że uzbrajają bombę. Oczywiście rozumiem, że to uzbrajanie wynika też z tego, że tak jak niski jest prestiż zaprojektowany przez pensję zawodu nauczyciela, tak niski jest prestiż humanistyki, bo właściwie nikt specjalnie serio nie bierze założenia, że ważne jest wykształcenie humanistyczne. Ważne są różne prestiżowe zawody, do których to wykształcenie nie jest niezbędne, choć badania przytoczone na początku naszej rozmowy prowadzą do innych wniosków. Wszyscy, którzy myślą, że trzeba uczyć tylko kanonu narodowego, oprócz tego świetnie kształcić informatyków, pracują na to, że ci informatycy jednak sięgną do swojego doświadczenia, do swojego zasobu filmów, gier komputerowych i tego wszystkiego, co otwiera, co anarchizuje, co daje wolność, co daje wybór, i rozwalą ten system.

P.Ś.: Otóż to: to nie będzie bunt przeciwko tak skonstruowanej szkole, ale to będzie bunt przeciwko tym sfałszowanym, nieatrakcyjnym, opresywnym rzekomym wartościom, które są przez tę konserwatywną, regresywną czy retrospektywną rewolucję lansowane. Jeśli się komuś wmawia, narzuca zdefiniowaną, jednoznaczną, nieodpowiadającą jego doświadczeniu kulturę literacką, to się go impregnuje na kulturę w ogóle, oddala od niej, czyni ją obcą. Jak to jest, że mamy tak niskie czytelnictwo, skoro mamy tak wiele lekcji polskiego przez tyle lat? To jest miarą klęski szkoły. A dlaczego szkoła poniosła taką klęskę? Przez rewolucję konserwatywną, przez to, że ona jest po prostu na konserwatyzm skazana, na obojętność na to, z kim pracuje, do kogo jest adresowana. W liberalnym porządku ci, którzy uważają, że jesteśmy niepotrzebni, niestety mają do jakiegoś stopnia rację (tak między nami). Jeśli jedyną miarą skuteczności, która by nas interesowała, jest stworzenie z ucznia czytelnika, czyli człowieka, który jest zdolny do bezinteresownego rozwijania opowieści o sobie i o świecie, to ponieśliśmy jakąś potworną klęskę.

K.B.: Konserwatyści boją się tego, o czym mówił wczoraj Ryszard Koziołek, że właściwie już nie ma wspólnych lektur. W związku z tym dajmy Dziady, Kordiana, będziemy mieli coś wspólnego.

A.J.S.: Mnie się wydaje, że powrót do kanonu sprzed trzydziestu lat tłumaczy powody tego lęku, bo utrata kanonu jest utratą jakiegoś porząaku, a ten porządek warunkował wartości, do których autorzy nowej podstawy programowej w jakiejś mierze byli przywiązani. Zachwianie kanonu oznacza według nich atrofię wartości i chaos w świecie pozbawionym mocnych punktów oparcia, takich jak czytane od pokoleń te same lektury. Pluralizm w kulturze jest tak naprawdę zgodą na pluralizm różnych poglądów, więc już to burzy „jedynie 
słuszny” porządek. Kultura, a przede wszystkim literatura, uczy otwartości na różne porządki, na światy alternatywne, więc misją nauczyciela jest właśnie otwierać na ten pluralizm i na te inne porządki.

P.Ś.: Konserwatysta ma pewne obsesje. Z całym szacunkiem dla konserwatystów, pośród których byli i są również ludzie wybitni, ale w praktyce konserwatystą kierują obsesje - na przykład seksualna, obsesja kontroli w tej dziedzinie. Kanon wyobraża sobie nie jako więź, ale jako wędzidło na samodzielność, krytycyzm, elastyczność. Uczeń nie tyle ma samodzielnie myśleć, kształtować się i dostosowywać, ile właśnie ma być prowadzony w z góry i raz na zawsze wytyczoną stronę. Może to jest krzywdzące, że to konserwatyści wymyślili, ale jeśli to są konserwatyści, to oni nas wiodą w obojętność, pustkę, czynią z nas zjawisko archeologiczne, żywą skamielinę i raczej nie wyobrażam sobie, żeby mogło być inaczej...

A.J.S.: ...I to może im się udać, bo jak pokazują na przykład badania czytelnictwa, jest taki trend zupełnie przeciwny do tego, co było dawniej, kiedy mnóstwo i o wiele chętniej czytało się poza lekturami narzuconymi przez szkołę. Ostatnie badania pokazują, że jest wielu młodych ludzi, szczególnie chłopców, którzy czytają wyłącznie lektury obowiązkowe, nic poza nimi, a wiadomo, że po maturze nie ma już potrzeby tego czytania, nie ma bowiem egzaminacyjnego straszaka, więc jeżeli ich czytelnictwo kończy się właśnie na szkolnym kanonie, a do tego dojdzie jeszcze kanon odczytań, to staje się to niebezpieczne.

K.B.: Tak, kanon odczytań jest najbardziej niebezpieczny, bo to nie jest tak, że ci młodzi ludzie czytają Dziady i czytają Lalkę, tylko czytają nadbudowaną nad tym całą strukturę odczytań, które nie zawsze fałszują, ale ujednoznaczniają. Dziady czytamy jako martyrologię, a przecież możemy w nich czytać o wolności, o metafizyce, wiemy, że można iść w przeróżne strony. Podobnie jest z Lalka. Sam kiedyś napisałem esej Moje Lalki... Policzyłem, że przeczytałem Lalkę siedem razy i za każdym razem to była zupełnie inna Lalka. Tym bardziej młodzi ludzie mogą czytać w przeróżny sposób, tymczasem narzuca im się to, że na przykład Izabela za każdym razem jest zła.

P.Ś.: To jest właśnie kwestia pozwolenia.

A.J.S.: Są znakomite współczesne odczytania klasyki romantycznej. Grażyna Tomaszewska napisała kilka książek z podpowiedziami dla nauczycieli, jak można prowadzić mądre lekcje, jak otwierać na nowe interpretacje. Przykładem może być czytanie Zygmunta Krasińskiego kluczem feministycznym, Dziadów z punktu widzenia problemów i buntu współczesnego młodego człowieka, a to może otworzyć przed uczniem nowe literackie światy, więc, broń Boże, nie wyrzucajmy tych książek, tylko otwierajmy na inne odczytania. 
K.B.: Tylko stajemy przed problemem zupełnie fundamentalnym, ponieważ w dużej mierze tych tekstów młodzi ludzie po prostu nie rozumieją w sensie literalnym. Nie mówię przy tym o Odprawie postów greckich, którą trzeba im właściwie przetłumaczyć... Chodzi o większą część klasyki. Uczniowie mogą zrozumieć, ale trzeba dużo czasu, żeby wejść w głąb tych tekstów.

A.J.S.: Mówimy o dwóch fundamentalnych kwestiach. Po pierwsze trzeba podnieść pensje dla nauczycieli, żeby najlepsi nauczyciele trafiali do szkół, bo tylko tacy otworzą uczniów na literaturę. Po drugie nauczyciele powinni mieć czas. O tym mówił też dziś Jarosław Mikołajewski, że na przykład we Włoszech mają rok na omawianie Dantego i to jest dobre przygotowanie do każdej innej lektury.

\section{I.I.: Miesiąc na Dziady.}

P.Ś.: Zasadniczo związane z postulatami Pani Profesor jest to, o czym mówiła Inga, czyli zwolnić szkołę z efektów kształcenia. Nie możemy powiedzieć, że będziemy czytali naprawdę różnorodnie, cały czas mając nad sobą jakiś rodzaj sprawdzianu, kontroli tego, czego nauczyliśmy.

A.J.S.: Może nie chodzi o zupełne zwolnienie z efektów kształcenia, ale efektem kształcenia powinno być krytyczne czytanie.

P.Ś.: Ale wtedy uchylamy kontrolę, bo prawdziwie krytycznego czytania nie jesteśmy w stanie skontrolować, nie możemy zestandaryzować, bo wówczas byłoby to wewnętrznie sprzeczne. Ta standaryzacja po prostu zniszczyła bardzo dużo. Oczywiście banał funkcjonował przez dziesięciolecia, ale zamieniony na rzekomą funkcjonalność nie przestał być banałem, natomiast stał się śmiertelnie nudny, wewnętrznie ograniczony, pozbawiony emotywności. Banał może być wartościowy, kiedy jest nasycony emocją. Jeśli to, co my uznamy za banał, jest dla ucznia wartościowym doświadczeniem emocjonalnym, to przestaje być banałem, bo jednak coś otwiera. Jednak system kontroli i oczekiwań w stosunku do nauczyciela właściwie to wyklucza. Tkwimy w utopii, kiedy mówimy, że możemy czytać inaczej, dlatego że to nie zdaje mi się w obecnych warunkach nawet trochę możliwe. Nauczyciel, który sobie na to pozwala, będzie musiał za pewien czas coś odpracować, odrobić. To są bardzo konkretne przykłady. Jest tutaj na kongresie pani Anna Nakielska z Bydgoszczy, którą znam ze względu na to, że od lat przyjeżdża ze swoimi uczniami na różne imprezy w Poznaniu, a także na Festiwal Conrada do Krakowa. To są wyczerpujące wyprawy, nieujęte w żadnym spisie obowiązków. Pani profesor wychowuje fantastycznych polonistów, którzy przychodzą również do nas na studia. To, co robi, graniczy z cudem. Ale w szkole wydaje mi się osamotniona, pozbawiona wsparcia, 
skazana na nieustannie kombinowanie środków niezbędnych do prowadzenia swojej działalności.

Porządek szkolny jest więc porządkiem wewnętrznie dławiącym. Mamy do czynienia z podwójnym uwikłaniem czy zapętleniem - zdaje się, że jest takie pojęcie psychologiczne. Składa się na nauczyciela pewne obowiązki, żeby budził, kształtował, wzbogacał młodego człowieka, po czym ta sama instytucja, która tego od niego oczekuje, uniemożliwia mu dojście do celu. To jest do zrobienia tylko przez charyzmatycznych, szalonych, czasami mdlejących ze zmęczenia nauczycieli.

A.J.S.: Wrócę do kwestii czasu, bo on jest naprawdę bardzo istotny. Zło nowej podstawy programowej polega na tym, że ona nieprawdopodobnie odbiera wolność nauczycielom przez nadmiar szczegółowych instrukcji, konkretów, liczby obowiązkowych tytułów. Nauczyciele już nie mają tego marginesu, który pozwalałby im wybierać teksty odpowiadające potrzebom i oczekiwaniom uczniów, a także własnej pasji, którą mogliby ich zarazić. Tymczasem kiedy podczas protestu przeciw reformie dotarliśmy przed oblicze pani minister, wiceministra i twórców podstawy programowej i kiedy poruszyliśmy między innymi temat przeładowania listy lektur i zbyt wielkiej liczby wymagan, usłyszeliśmy od pani minister pełne ignorancji słowa, że ona by ten program zrealizowała w pół roku.

Niestety, nauczyciele muszą mieć więc odgórnie zadekretowaną wolność, podobnie jak jest to wpisane w programach angielskich: nie ma nic ważniejszego niż wsparcie dla indywidualnego ucznia. Kiedy odwiedzaliśmy brytyjskich nauczycieli i pytaliśmy, jak wypadają w rankingu PISA, okazywało się, że ich to nie obchodzi. Mówili: dla mnie liczy się człowiek, który siedzi przede mną, w czym mogę mu pomóc, co mogę dla niego zrobić, jak mogę rozpoznać trudności, z którymi się mierzy, a jak zdolności, i jak mogę sprawić, żeby było mu lepiej, wiedział więcej, zdobył później lepszą pracę, był lepszym człowiekiem. Angielscy pedagodzy mają to właściwie zadekretowane w ich curriculum i nie ma dla nich nic ważniejszego. Nauczyciel musi mieć więc zadekretowaną tę wolność, swobodę i świadomość, że jest odpowiedzialny za każdego poszczególnego ucznia, a nie za to, czy klasa dokładnie zrozumie, odczyta intencje autora sprzed wieków i dojdzie do jedynych słusznych wniosków.

P.Ś.: Tak jak w tych starych testach: czy to jest synekdocha czy metonimia? Punkt jest albo go nie ma. To jest przerażające.

K.B.: Jeśli chodzi o wolność nauczycieli, to też mamy jakieś doświadczenie, bo poprzednia podstawa programowa dawała pewien zakres wolności. W tym obszarze, gdzie nauczyciele mogli wybierać, wybierali jednak najczęściej teksty kanoniczne z przeszłości. W szkole podstawowej w klasach od pierwszej do trzeciej, gdzie nie było żadnych lektur obowiązkowych, kazano czytać dzieciom 
Plastusiowy pamiętnik - rzecz zupełnie niezrozumiałą dla dzieci, które nie wiedzą, co to jest obsadka, stalówka itd. Nauczyciele byli przekonani, że to jest właśnie ten kod kulturowy, że bez Plastusiowego pamiętnika nie da się wytłumaczyć świata. Dlatego trzeba przemodelować to, jak literaturę widzą sami nauczyciele. W tej chwili jesteśmy w strasznie trudnej sytuacji, bo wolność trzeba praktykować, natomiast w momencie kiedy się ją odbiera pod pretekstem, że nauczyciele nie potrafili korzystać z tej wolności, to tej wolności nigdy nie będzie.

I.I.: To jest chyba akurat też zadanie dla nauczycieli akademickich, dla tych środowisk, które zajmują się przygotowywaniem propozycji kanonów (wielu), podręczników, materiałów pomocniczych itd. Jeśli jest z czego wybierać, to może nie wybiera się automatycznie Plastusiowego pamiętnika...

\section{A.J.S.: Dokładnie tak jest. Nauczyciele nie widzą teraz alternatywy.}

\section{I.I.: Trzeba im pokazać, być partnerem/partnerką w tej dyskusji.}

P.Ś.: Po prostu rozmawiać o tym. Kiedyś Ośrodek Doskonalenia Nauczycieli poprosił mnie o poprowadzenie warsztatów z interpretacji wierszy dla chętnych nauczycieli. Kiedy nie dyktowałem żadnego schematu interpretacyjnego, tylko po prostu przynosiłem nieznane wiersze, żebyśmy o nich rozmawiali, to najpierw miałem wrażenie, że było to rozczarowujące, bo właśnie nie podpowiadałem rozwiązań, ale ponieważ tych spotkań było kilka, to po jakimś czasie sytuacja zupełnie się odwróciła i nie byłem tam żadnym przewodnikiem, po prostu proponowałem teksty i to było chyba najważniejsze, co robiłem. Rozmowy, inwencja nauczycieli były kapitalne. W końcu ich namówiłem, żeby napisali pastisze tych wierszy, co mi się wydawało niemożliwe, byłem pewien, że się na to nie zgodzą, ale dorośli ludzie z różnym stażem z zapałem pisali bardzo ciekawe teksty. To jest jakaś metoda na to, żeby zobaczyć poetykę od innej strony - nie opisowej, nie czysto encyklopedycznej. Poza tym ważne było to, że ci nauczyciele mieli poczucie dostępu do literatury współczesnej, co nie jest takie proste, jeśli się ktoś nie interesuje nią systematycznie.

A.J.S.: Wydaje mi się, że to jest właśnie trzeci warunek, który musi być spełniony, aby poprawić sytuację, czyli powinno się nauczycielom udzielić wsparcia, które w dużej mierze ma polegać na ich ciagłym kontakcie z tym, co ważne, aktualne, a przede wszystkim współczesne. Oni wychodzili ze szkół, w których współczesność kończyła się na dwudziestoleciu międzywojennym. Nie lepiej bywało na różnych uczelniach. Poza tym szkolni poloniści też niekiedy nie mają czasu czytać wszystkiego, co opublikowane, dokonywać selekcji, wyboru. Dopominaliśmy się bezskutecznie w ministerstwie, by nauczyciele mieli sfinansowaną możliwość uniwersyteckiego dokształcania. Teraz płacą z własnej kieszeni za kursy, szkolenia, o różnej, niestety, wartości, ale to nie znaczy, że oni 
nie chcą. To, że literatura współczesna jest nieobecna na lekcjach, bardzo często wynika z faktu, że oni właściwie nie wiedzą, co mogą zaproponować uczniom.

K.B.: Ja mam w ogóle taką utopijną koncepcję, żeby nauczyciele co siedem lat mieli sabbatical spędzany z powrotem na uniwersytecie, na pewno pozwalałoby to im nie tylko uzupełnić wiedzę, ale i poćwiczyć myślenie. A przy okazji łapaliby oddech od szkoły, co w tym zawodzie jest ogromnie ważne, bo tam bardzo szybko następuje wypalenie.

A.J.S.: To byłoby też powtórne wejście w rolę ucznia i sama ta zmiana perspektywy mogłaby być niesamowicie odświeżająca.

P.Ś.: Koniecznie, to jest świetny pomysł.

K.B.: To tym utopijnym akcentem spuentujmy naszą rozmowę. Dziękuję. 